with some 40 species, Clematis (9 spp.), Myosurus (one sp.), and Caltha (2 spp.).

The question naturally arises: How came the late Mr. T. F. Cheeseman to place this plant in the genus Ranunculus ? Dr. Sledge in the letter below sheds some light on this. He hopes to secure more material of this interesting plant, and when it is available, we may then be able to determine exactly its systematic position.

JoHN PARKIN.

Blaithwaite,

Wigton, Cumberland, May 25.

I MAY perhaps supplement Mr. Parkin's interesting observations on Ranunculus tenuicaulis Cheesem. This montane species is rare throughout New Zealand and of most frequent occurrence in Otago, in which province I collected it. Single stations are also given in Cheeseman's "Manual of the New Zealand Flora" (Ed. 2, p. 442) for Canterbury and Nelson, whilst in the North Island the plant has been collected in the Tararua Mts. The plant was first collected by Cheeseman in 1883 at Arthur's Pass in the Southern Alps of Canterbury, and there are single authentic specimens of this gathering in the herbaria at Kew and the British Museum. We are indebted to the authorities at Kew and the British Museum for descriptions of these plants, both of which are in ripe fruit and lack perianth members, as does a second specimen at Kew collected by Kirk in the same locality a year later. In his original description of the species (Trans. N.Z. Inst., vol. 17, 1884) Cheeseman writes, "Petals not seen"; and the inadequate references to the flowers in later descriptions in the "Manual", and particularly the absence of any reference to the very unusual and pronounced reddish colour of the perianth, would suggest that he never saw the plant in flower. His description of the achenes is more complete, and in the second edition of the "Manual" he adds the following note: "A very curious species, remarkable for the fusiform achenes and long spirally recurved styles". These "remarkable" facts are significant in view of $\mathbf{M r}$. Parkin's observations and the probable affinity of this plant with the genus Anemone. W. A. Sledge.

Botany Dept., University, Leeds, May 25.

\section{Reconstruction of an Indian Fossil Cycad}

Is 1900, Prof. Seward showed, in a specimen found at Amrapara in the Rajmahal Hills, pinnate leaves resembling Ptilophyllum cutchense McCl. sp. organically attached to a cycadean stem of the Bucklandia type. A Williamsonia flower discovered near the same locality a few years ago by Mr. G. V. Hobson of the Indian Geological Survey, and kindly placed at my disposal for description, proves to have belonged to the same plant as the Bucklandia. The stele of the peduncle shows that the wood is compact, as in the Bucklandia, and the structure of the bracts is identical in every way with that of the rhomboid leaf-bases preserved round the stem, which I have compared at the British Museum with kind permission of the authorities. There is also complete identity in structure with certain fragments of a Williamsonia flower, associated with another Bucklandia stem from Amrapara, described by Dr. N. Bancroft. ${ }^{2}$ The flower is unisexual and ovulate; in structure it closely resembles $W$. scotica Sew., from the Jurassic of Sutherland. ${ }^{3}$

In a restoration which I have attempted, the plant has the habit of a miniature Cycas, with the surface of the stem covered by alternating zones of large and small rhomboid scars. The flowering shoots are shown projecting laterally from the columnar trunk, attached by an attenuated base and turned upwards, like the vegetative buds of the living genus. The name $W$. Sewardiana has now been proposed for the plant in supersession of the name $W$. Sewardi previously chosen, ${ }^{4}$ as the latter name is preoccupied.

In view of our knowledge of the anatomy of the leaves, stem, and flower, this is now the best known species of Williamsonia.

University of Lucknow, April 28.

1 Jurassic Flora, “ Brit. Mus. Cat.”, 1900 ; “ Foss. Plants ”, 3, 488, $489 ; 1917$.

2 Trans. Linn. Soc., p. $76 ; 1913$.

3, $101 ; 1912$.

" See Seward, "Plant Life", p. 356 ; 1931

\section{The pH Stability Region of Proteins and Osmotic Swelling}

THe swelling of protein gels and tissues under the influence of acid or alkali is due mainly to osmotic forces set up on account of salt formation between the protein and the acid or base. Osmotic swelling always shows two well-marked maxima, one in the acid and one in the alkaline range, and it has generally been taken for granted that the $p \mathrm{H}$-swelling curve should also show a sharply marked minimum corresponding to the iso-electric point of the protein. This misconception has arisen from the fact that the bulk of the work on the swelling and osmotic pressure of proteins has been done on gelatin and albumin, both of which

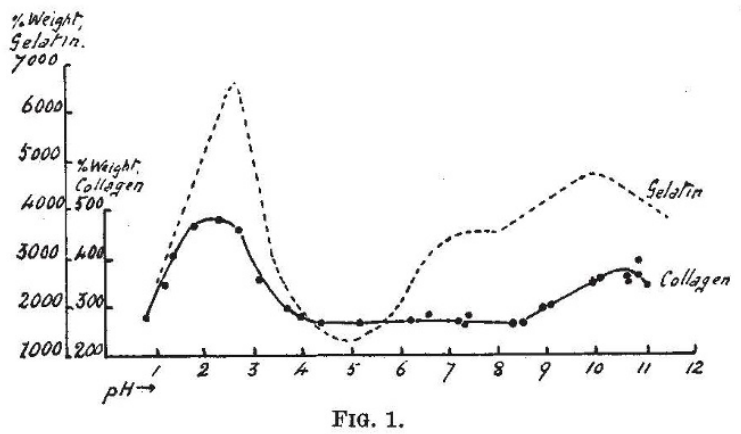

show sharply marked minima, and where it is not unreasonable to assume that the protein molecules are present without any orientation.

A very different state of affairs manifests itself, however, in protein structures, where there is evidence that the protein molecules are oriented on a definite system, generally lying parallel to each other, with the possibility of cross linkages. Examples of the effect of hydrogen ion concentration on swelling of proteins of this type show the appearance of a range of $p H$ stability which becomes more emphatic with the development of a definite fibrous structure; muscle proteins, for example, have a stability range (roughly measured) of $p \mathbf{H}$ 5-7 or possibly 8.1 The $p$ H-swelling curve for collagen fibres is shown in the accompany. ing diagram (Fig. 1), together with the smoothed curve for gelatin. The contrast is striking, the curve for gelatin showing a sharp minimum at $p \mathrm{H} 5$ and that for collagen fibres a stability range of $p H 4-8 \cdot 5$.

Keratin fibres (horse-hair) and silk fibres do not show osmotic swelling at any $p \mathrm{H}$ value, but begin to show swelling due to the breakdown of the structure by alkali at about $p H$ 11-13. Speakman ${ }^{2}$ has, however, shown that keratin fibres (wool) have a stability region against stretching forces of $p \mathrm{H} 4-8$, and has 